\title{
Pathways, activities and thermal stability of anaerobic and aerobic enzymes in thermophilic vent paralvinellid worms
}

\author{
C. Rinke*, R. W. Lee \\ School of Biological Sciences, Washington State University, 99164 Pullman, Washington, USA
}

\begin{abstract}
Animals living at deep sea hydrothermal vents experience high values of both temperature and hypoxia/sulfide. In these harsh environments polychaetes represent an important proportion of the biomass and diversity. To determine the mechanisms facilitating survival, we investigated the activities and thermal stability of 6 enzymes functioning under anaerobic and aerobic conditions, as well as glycogen levels, in 2 paralvinellid species from hydrothermal vents. In addition, the enzyme activities of several polychaetes from hydrocarbon cold seeps, which encounter low oxygen and high sulfide, but not elevated temperature, were investigated for comparative purposes. 'Anaerobic' (lactate dehydrogenase, opine dehydrogenases) and 'aerobic' enzyme (citrate synthase) activities of hydrothermal vent paralvinellids were similar to those of shallow water polychaetes, and significantly higher than those in cold seep species. Surprisingly, we detected different metabolic pathways in various body parts of hot vent species. The branchiae were identified to be the body part in which aerobic metabolism likely dominates, whereas the body wall is the major focal point of anaerobic glycolysis. Enzyme activity levels remained nearly constant in paralvinellids maintained for up to $120 \mathrm{~h}$ in high-pressure chambers. Thermal stability observations of in vitro enzyme activities showed stability after exposure to elevated temperatures: up to $60^{\circ} \mathrm{C}$ for lactate dehydrogenase and up to $50^{\circ} \mathrm{C}$ for opine dehydrogenases, the latter correlating with the preferred temperatures of living paralvinellids. Heat shock experiments with live specimens revealed lethal temperatures of $45^{\circ} \mathrm{C}$ for Paralvinella palmiformis and $63^{\circ} \mathrm{C}$ for P. sulfincola. Heat shock treatments also reduced enzyme activity. Glycogen levels in vent species were lower than in shallow water species, suggesting that paralvinellids can obtain carbon through feeding under anoxic conditions.
\end{abstract}

KEY WORDS: Hydrothermal vent · Paralvinellids · Temperature · Hypoxia · Glycogen · Cold seep · Dehydrogenase $\cdot$ Citrate synthase

\section{INTRODUCTION}

Deep sea hydrothermal vents are known to represent a harsh environment for animals (McMullin et al. 2000). The hydrothermal vent fluid contains high levels of heavy metals, $\mathrm{CO}_{2}$, and sulfide, but with no oxygen and low pH (Tunnicliffe 1991, Magenheim \& Gieskes 1992). Mixing of the vent fluid with ambient deep-sea water is believed to strongly affect the surrounding environment and associated animal communities. Polychaetes are among the most successful spe- cies coping with these challenging conditions. Of particular interest are paralvinellids (members of the family Alvinellidae), since they can inhabit the highest temperature niches of metazoans. Recently, it has been shown that Paralvinella sulfincola prefers temperatures between 40 and $50^{\circ} \mathrm{C}$ (Girguis \& Lee 2006) and can survive up to $60^{\circ} \mathrm{C}$ (Lee 2003). However, a rather low habitat temperature range from about 5 to $22^{\circ} \mathrm{C}$ and hydrogen sulfide values from 20 to $100 \mu \mathrm{mol} \mathrm{l} \mathrm{l}^{-1}$ have been recorded by in situ measurements at the Juan de Fuca Ridge (Sarrazin et al. 1999). P. palmi- 
formis co-occurs at vent sites with $P$. sulfincola, but colonizes different niches with lower temperatures (5 to $14^{\circ} \mathrm{C}$; Sarrazin et al. 1999) and less hydrogen sulfide with about 20 to $65 \mu \mathrm{mol} \mathrm{l}^{-1}$. P. palmiformis specimens also avoided temperatures $>35^{\circ} \mathrm{C}$ in in vivo experiments (Girguis \& Lee 2006), and died at temperatures $>40^{\circ} \mathrm{C}$ (Lee 2003).

Environmental biochemical adaptations in these species are less well characterized than those in the thermophilic alvinellid Alvinella pompejana, which inhabits the high temperature niche at East Pacific Rise vents (e.g. Cary et al. 1998, Chevaldonné et al. 2000).

Biochemical evidence indicates that high temperature alvinellids have macromolecules that are thermally stable at temperatures up to $50^{\circ} \mathrm{C}$. These findings are consistent with a likely ability to tolerate sustained exposure, at perhaps as high as 40 to $45^{\circ} \mathrm{C}$, but an inability to persist indefinitely at temperatures $>50^{\circ} \mathrm{C}$. Enzyme and other macromolecule structures/ functions of Alvinella pompejana are perturbed at temperatures approaching $50^{\circ} \mathrm{C}$. Collagen from A. pompejana melts at around $46^{\circ} \mathrm{C}$ (Gaill et al. 1991), and $A$. pompejana hemoglobin structure/function studies indicate protein instability at $50^{\circ} \mathrm{C}$ (Terwilliger \& Terwilliger 1984) and optimal oxygen binding at from 20 to $30^{\circ} \mathrm{C}$ (Toulmond et al. 1990). A linear relationship has been observed between enzyme kinetics and maximal sustained body temperature (Dahlhoff et al. 1990), which suggests that the maximal sustained temperature for A. pompejana is around $30^{\circ} \mathrm{C}$. Physiological measurements of isolated mitochondria have shown that the Arrhenius break temperature for A. pompejana mitochondrial respiration is $48.6^{\circ} \mathrm{C}$ (Dahlhoff et al. 1991). Recent comparative analysis of mitochondrial Arrhenius breakpoints indicates that 55 to $60^{\circ} \mathrm{C}$ may be the limit for all metazoan life (Hochachka \& Somero 2002).

In addition to high temperature, reduced oxygen availability is a challenge for hot vent animals like alvinellids. Adaptations for improved oxygen uptake, such as higher blood $\mathrm{O}_{2}$ affinities and more efficient respiratory organs, have been described for alvinellids and other hydrothermal vent species (Hourdez \& Lallier 2007). Probable periods without oxygen supply, as well as the recorded high levels of sulfide (Sarrazin et al. 1999), which can poison the mitochondrial electron chain and disrupt aerobic metabolism (Grieshaber \& Völkel 1998), increase the importance of anaerobic metabolic pathways. Anaerobic metabolism has been investigated in the symbiotic tubeworm Riftia pachyptila (Arndt et al. 1998), but is less well characterized in alvinellids. Such studies have mainly focused on adaptations of benthic shallow water polychaetes and show lactate and opine dehydrogenases as the most common pathways (e.g. Schöttler \& Bennet 1991), as well as energetically improved fermentation pathways and glycogen as the major energy source during anaerobiosis (Grieshaber et al. 1994). A positive correlation between glycogen concentrations and environmental anoxia has been observed in shallow water polychaetes (Von Brandt 1927, Augenfeld 1978).

The aim of the present study was to determine the importance of anaerobic and aerobic pathways in polychaetes that encounter low oxygen and high sulfide. To evaluate anaerobic pathways we quantified the enzyme levels of lactate and opine dehydrogenases. The role of the aerobic metabolism was determined based on the activity of citrate synthase. We sampled 2 Paralvinella species ( $P$. sulfincola and $P$. palmiformis) occupying distinct chemical and thermal niches in areas of elevated temperature at hydrothermal vents in the East Pacific. Our hypothesis was that the different environmental conditions encountered by these species are reflected in different enzyme activity levels. These data were compared to results for polychaetes from cold hydrocarbon seeps, a very low oxygen and high hydrogen sulfide environment (see Levin et al. 2003, McMullin et al. 2000) with low temperatures. We tested the hypothesis that polychaetes living at cold seeps have lower metabolic activity (lower enzyme activity levels) than do hot vent species. To investigate the ability of hot vent paralvinellids to cope with elevated temperatures, we determined enzyme activities after exposure of tissue extracts to different temperatures, and applied heat shock experiments with living specimens, quantifying the resulting consequences on survival and enzyme activities. Our hypothesis proposed that $P$. sulfincola inhabiting higher temperature niches than $P$. palmiformis is more heat tolerant and so are its enzymes. Furthermore, we monitored enzyme levels of paralvinellids under air-saturated seawater conditions for up to $120 \mathrm{~h}$ to test if anaerobic enzyme activities are sustained. Glycogen storage levels of paralvinellids were compared to shallow water species to evaluate the hypothesis that the risk of anoxia is reflected in the amount of stored glycogen.

\section{MATERIALS AND METHODS}

Sample collection. The submersible 'Alvin' was used to capture paralvinellid polychaetes in September 2007 at a depth of 2198 to $2230 \mathrm{~m}$ at the hydrothermal vents in the Main Endeavour vent field (47 $57^{\prime} \mathrm{N}$, $129^{\circ} 05^{\prime} \mathrm{W}$ ) on the Juan de Fuca Ridge in the northeastern Pacific. All samples were taken with Alvin's multichambered suction sampler. Alvin was also used to collect hydrocarbon seep polychaetes in 2006 at 775 to $785 \mathrm{~m}$ depth on the Hydrate Ridge $\left(44^{\circ} 34^{\prime} \mathrm{N}\right.$, $125^{\circ} 08^{\prime} \mathrm{W}$ ) in the northern Pacific. Due to the soft bot- 
tom habitat characteristics on the Hydrate Ridge, samples were taken with sediment push cores. Subsequent to arrival of the submersible at the surface, samples were sorted out in the cold room $\left(5^{\circ} \mathrm{C}\right)$, and only living animals responding to physical stimulus without any visible injuries were picked for further experiments or were flash frozen. It has to be noted that in contrast to Alvinella pompejana specimens, which usually are not able to survive collection and recovery, paralvinellids do not seem to be harmed by this procedure. For example, Paralvinella palmiformis specimens survived $>24 \mathrm{~h}$ at ambient pressure in the ship's cold room $\left(5^{\circ} \mathrm{C}\right)$.

Enzymatic assays. Frozen samples stored at $-80^{\circ} \mathrm{C}$ were dissected on ice into the branchiae and body wall (hot vent samples), or entire worms were used (cold seep samples). Tissues were homogenized on ice after being diluted 1:20 in a $0.1 \mathrm{M}$ phosphate $(\mathrm{pH}$ 7) extraction buffer. Since citrate synthase activity is related to the extent of mitochondrial membrane disruption achieved in the assay, we used the ground glass-onglass pestle protocol (for all enzyme assays), which was found to be the best method for citrate synthase homogenization (Grace et al. 1996). Homogenates were centrifuged for $15 \mathrm{~min}$ at $15000 \times g$, and the supernatant was used for measuring enzyme activity at $25^{\circ} \mathrm{C}$ with a Shimadzu UV $160 \mathrm{U}$ spectrophotometer (Shimadzu). Conditions for the assays were as follows: (1) lactate dehydrogenase (LDH, EC 1.1.1.27) - $3 \mathrm{mM}$ pyruvate, $0.1 \mathrm{mM} \mathrm{NADH}, 100 \mathrm{mM}$ potassium phosphate, $\mathrm{pH} 7.4$; (2) alanopine dehydrogenase (ALPDH, EC 1.5.1.17) - $250 \mathrm{mM}$ alanine, $3 \mathrm{mM}$ pyruvate, $0.1 \mathrm{mM}$ NADH, $100 \mathrm{mM}$ potassium phosphate, $\mathrm{pH} 7.4$; (3) strombine dehydrogenase $(\mathrm{SDH}, \mathrm{EC}$ 1.5.1.22) - $250 \mathrm{mM}$ glycine, $3 \mathrm{mM}$ pyruvate, $0.1 \mathrm{mM}$ NADH, $100 \mathrm{mM}$ potassium phosphate, $\mathrm{pH} 7.4$; (4) octopine dehydrogenase $(\mathrm{ODH}, \mathrm{EC}$ 1.5.1.11) - 5.4 mM arginine, $3 \mathrm{mM}$ pyruvate, $0.1 \mathrm{mM}$ NADH, $100 \mathrm{mM}$ potassium phosphate, $\mathrm{pH} 7.4$; (5) tauropine dehydrogenase $(\mathrm{TDH}, \mathrm{EC}$ 1.5.1.23) - $80 \mathrm{mM}$ taurine, $3 \mathrm{mM}$ pyruvate, $0.1 \mathrm{mM}$ NADH, $100 \mathrm{mM}$ potassium phosphate, $\mathrm{pH} 7.4$; (6) citrate synthase (CS, E.C. 2.3.3.1 [previously 4.1.3.7])-1.01 $\mathrm{mM}$ DTNB, $10 \mathrm{mM}$ oxalacetate, $12.2 \mathrm{mM}$ acetyl CoA, $50 \mathrm{mM}$ imidazole- $\mathrm{HCl}$ buffer, $\mathrm{pH} 7.2$.

Activities of LDH, ALPDH, SDH, $\mathrm{ODH}$, and TDH were measured fol- lowing the oxidation of NADH at $343 \mathrm{~nm}$ and were corrected for unspecific oxidation. CS activity was determined by following the formation of thionitrobenzoic acid (TNB) at $412 \mathrm{~nm}$ and was corrected using a blank containing the same aliquot of homogenate, but without acetyl-CoA. Heat stability was tested by heating homogenates for $15 \mathrm{~min}$ at temperatures between 35 and $70^{\circ} \mathrm{C}$, followed by cooling on ice and determining enzyme activity at $25^{\circ} \mathrm{C}$ (Table 1 ). Enzyme activities were expressed as micromoles per minute per gram wet weight. Since all enzyme activities were determined at the same temperature $\left(25^{\circ} \mathrm{C}\right)$ and at $1 \mathrm{~atm}$ pressure and under standard assay conditions, they do not correspond to in vivo rates of catalysis. Thus, our measures are best interpreted as the relative enzymatic potential for anaerobic and aerobic respiration.

Glycogen digestion. Glycogen levels were determined by a method adapted from Passonneau \& Lauderdale (1974). Homogenates were diluted 1:1 in 1.94\% perchloric acid in order to extract the glycogen. Samples were then digested in amylo-1,6-glucosidase $\left(0.05 \mathrm{mg} \mathrm{ml}^{-1}\right)$, and $0.02 \%$ bovine serum albumin (BSA) in $0.5 \mathrm{M}$ sodium acetate, $\mathrm{pH} 5.5$, for $2 \mathrm{~h}$ at $25^{\circ} \mathrm{C}$. Blank (undigested) samples were prepared in the same way as the digested samples, except that amyloglucosidase was not added. Glycogen standards consisting of bovine liver glycogen (Sigma Type IX, 85\%)

Table 1. Paralvinella sulfincola, P. palmiformis. Number of individuals used for enzyme thermal stability experiments shown in Fig. 2. LDH: lactate dehydrogenase (anaerobic metabolism); ALPDH: alanopine dehydrogenase (anaerobic metabolism); SDH: strombine dehydrogenase (anaerobic metabolism); CS: citrate synthase (aerobic metabolism)

\begin{tabular}{|c|c|c|c|c|c|c|c|c|}
\hline & \multirow{2}{*}{ Tissue } & \multicolumn{7}{|c|}{ - Temperature $\left({ }^{\circ} \mathrm{C}\right)$} \\
\hline & & 35 & 40 & 45 & 50 & 55 & 60 & 70 \\
\hline \multicolumn{9}{|l|}{ LDH } \\
\hline \multirow{2}{*}{ P. sulfincola } & Branchiae & & 10 & & 10 & 6 & 10 & 6 \\
\hline & Body wall & & 10 & & 10 & 6 & 10 & 6 \\
\hline \multirow[t]{2}{*}{ P. palmiformis } & Branchiae & 5 & 12 & & 9 & & 10 & 7 \\
\hline & Body wall & 5 & 12 & 7 & 9 & & 10 & 8 \\
\hline \multicolumn{9}{|l|}{ ALPDH } \\
\hline \multirow[t]{2}{*}{ P. sulfincola } & Branchiae & & 10 & & 10 & 6 & 10 & 4 \\
\hline & Body wall & & 10 & & 10 & 6 & 10 & 4 \\
\hline \multirow[t]{2}{*}{ P. palmiformis } & Branchiae & 5 & 9 & & 6 & & 6 & 4 \\
\hline & Body wall & 5 & 9 & 7 & 6 & & 7 & 5 \\
\hline \multicolumn{9}{|l|}{ SDH } \\
\hline \multirow[t]{2}{*}{ P. sulfincola } & Branchiae & & 10 & & 10 & 6 & 10 & 4 \\
\hline & Body wall & & 10 & & 10 & 6 & 10 & 4 \\
\hline \multirow[t]{2}{*}{ P. palmiformis } & Branchiae & 5 & 9 & & 9 & & 6 & 7 \\
\hline & Body wall & 5 & 9 & 7 & 9 & & 7 & 8 \\
\hline \multicolumn{9}{|l|}{ CS } \\
\hline \multirow[t]{2}{*}{ P. sulfincola } & Branchiae & & 13 & 4 & 7 & & 4 & 3 \\
\hline & Body wall & & 14 & 6 & 7 & & 4 & 3 \\
\hline \multirow[t]{2}{*}{ P. palmiformis } & Branchiae & & 12 & & 13 & 5 & 7 & 4 \\
\hline & Body wall & & 12 & & 14 & 6 & 7 & 4 \\
\hline
\end{tabular}


were digested as described for the homogenates and were used to confirm digestion efficacy. Following digestion, samples were centrifuged $(10000 \times g$, $10 \mathrm{~min}$ ), and the supernatants were assayed for glucose using the glucose (HK) assay kit (Sigma) and an EL 340 biokinetics reader (Bio-Tek Instruments). Glycogen content was expressed as milligrams glycogen per gram wet weight.

Pressurized aquaria experiments. Paralvinella palmiformis specimens were pressurized in anodized aluminum aquaria at 3000 psi (207 bar), similar to in situ pressure at $2000 \mathrm{~m}$, immediately after recovery of the submersible and sorting out at $5^{\circ} \mathrm{C}$. HPLC (highperformance liquid chromotography) high-pressure pumps (Beckman) constantly provided air-saturated seawater flow through the aquaria. Temperature was kept constant at $5^{\circ} \mathrm{C}$ during the entire experiment, and polychaetes were visually inspected through acrylic glass windows for movement.

Temperature shock experiments. Paralvinellids were kept in pressure chambers containing a digital thermometer probe at initial temperatures of 10 to $20^{\circ} \mathrm{C}$. Temperature was quickly raised to between 30 and $63^{\circ} \mathrm{C}$ over 2 to $5 \mathrm{~min}$, followed by rapid cooling on ice. Then, 2 to 6 heating and cooling trials were conducted on each set of 2 to 5 individual paralvinellids. Behavior was observed during the time course of heating and cooling. Death was determined when no movement following cooling and reheating could be observed. Trials with Paralvinella sulfincola involved individuals that were collected the same day. Some trials with $P$. palmiformis involved individuals maintained in pressure chambers at in situ pressure. Several $P$. sulfincola specimens that survived temperatures between 58 and $60^{\circ} \mathrm{C}$ were used for enzyme assays after completing the heat shock series. Additionally, $P$. sulfincola specimens were heated to $60^{\circ} \mathrm{C}$ over 2 to $5 \mathrm{~min}$, starting from $2^{\circ} \mathrm{C}$ in pressure chambers, and then frozen for enzyme activity measurements.

Statistics. Using the software SPSS V. 12.0, the modified Kolmogorov-Smirnov test of normality did not reveal normal distributions for any of the data tested. Therefore, non-parametric statistics were applied, using the Mann-Whitney $U$-test, with a $99 \%$ confidence interval to compare datasets.

\section{RESULTS}

\section{Enzyme activities}

Body wall homogenates of the hydrothermal vent polychaetes Paralvinella sulfincola and P. palmiformis showed similar enzyme activity patterns. Among the 'anaerobic' enzymes, the activity of LDH was low for
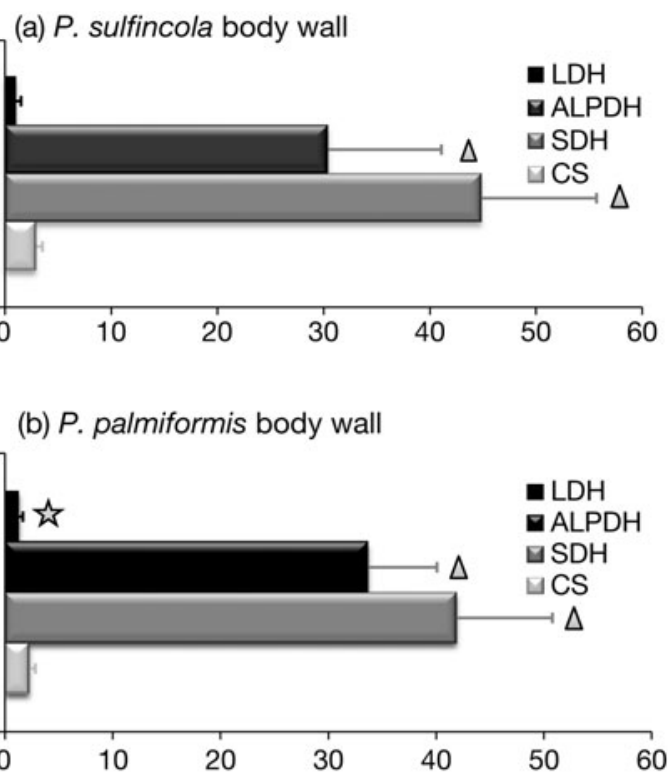

(c) P. sulfincola branchiae

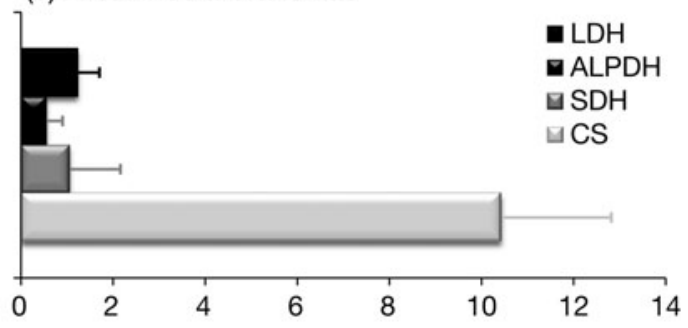

(d) P. palmiformis branchiae

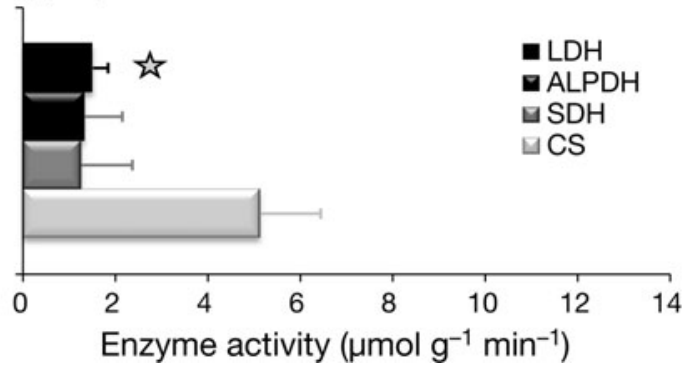

Fig. 1. Paralvinella sulfincola, Paralvinella palmiformis. Enzyme activities of $(\mathrm{a}, \mathrm{c}) P$. sulfincola and $(\mathrm{b}, \mathrm{d}) P$. palmiformis homogenates from hydrothermal vents at the Juan de Fuca Ridge (East Pacific). (a, b) Enzyme activities in the body wall, (c, d) enzyme activities in the branchiae (gills). Levels of enzyme activities differ significantly between tissues within each paralvinellid species, except for LDH of $P$. palmiformis (indicated by a star). All enzyme activities differ significantly within tissues between paralvinellid species, except for ALPDH and SDH body homogenates (indicated by triangles). Note the different scales on the $x$-axis. LDH: lactate dehydrogenase (anaerobic metabolism); ALPDH: alanopine dehydrogenase (anaerobic metabolism); SDH: strombine dehydrogenase (anaerobic metabolism); CS: citrate synthase (aerobic metabolism). Error bars $=\mathrm{SD}$ 
Table 2. Enzyme activities ( $\mu \mathrm{mol} \mathrm{g}^{-1}$ wet weight $\mathrm{min}^{-1}$ ) in various polychaetes of lactate dehydrogenase (LDH), alanopine dehydrogenase $(\mathrm{ALPDH})$, strombine dehydrogenase (SDH), octopine dehydrogenase (ODH), tauropine dehydrogenase (TDH), and citrate synthase (CS). The tissue homogenates used for measurements were entire animal (en), branchiae (br), and body wall (bw). Where the number of individuals (N) differs between enzymes, a range from lowest to highest number is given. A value of 0 means no enzyme activity was observed; no value means it was not investigated; a dash means unknown

\begin{tabular}{|c|c|c|c|c|c|c|c|c|c|}
\hline & $\mathrm{N}$ & Tissue & $\mathrm{LDH}$ & ALPDH & $\mathrm{SDH}$ & $\mathrm{ODH}$ & $\mathrm{TDH}$ & CS & Source \\
\hline \multicolumn{10}{|l|}{ Hydrothermal vents } \\
\hline Paralvinella sulfincola & $17-18$ & br & 1.24 & 0.55 & 1.06 & 0 & 0 & 10.43 & Present study \\
\hline$P$. sulfincola & 18 & bw & 1.03 & 30.44 & 44.84 & 0 & 0 & 2.90 & Present study \\
\hline Paralvinella palmiformis & $17-21$ & br & 1.51 & 1.33 & 1.26 & 0 & 0 & 5.12 & Present study \\
\hline P. palmiformis & $18-22$ & bw & 1.31 & 33.71 & 41.90 & 0 & 0 & 2.25 & Present study \\
\hline Paralvinella grasslei & 7 & $\mathrm{br}$ & & & & & & 5.4 & Marie et al. (2006) \\
\hline P. grasslei & 7 & bw & & & & & & 2.3 & Marie et al. (2006) \\
\hline Alvinella pompejana & - & en & 2 & 23 & 62 & & & & Desbruyères et al. (1998) \\
\hline Riftia pachyptila & - & br & & & & & & 4.29 & Powell \& Somero (1986) \\
\hline R. pachyptila & - & bw & & & & & & 10.00 & Powell \& Somero (1986) \\
\hline \multicolumn{10}{|l|}{ Hydrocarbon seeps } \\
\hline Seep dorvilleid & 3 & en & 2.13 & 1.72 & 3.26 & 0 & 0 & 0.47 & Present study \\
\hline Ophryotrocha platykephale & 3 & en & 1.07 & 0.42 & 1.38 & 0 & 0 & & Present study \\
\hline Ampharetid & 7 & en & 0.37 & 0.20 & 0.76 & 0.34 & 0.23 & 0.44 & Present study \\
\hline Cold seep nereid & 9 & en & 4.39 & 0.14 & 0.23 & 0.17 & 0.25 & 0.82 & Present study \\
\hline \multicolumn{10}{|l|}{ Continental shelf } \\
\hline Cossura chilensis & 40 & en & 0 & 2.4 & 4.6 & & & & Gonzales \& Quinones (2000) \\
\hline Glycera americana & 4 & en & 0.60 & 52.5 & 10.8 & & & & Gonzales \& Quinones (2000) \\
\hline Lumbrineris composita & 4 & en & 0.3 & 0.2 & 0 & & & & Gonzales \& Quinones (2000) \\
\hline Nephtys ferruginea & 12 & en & 0.13 & 6.1 & 5.8 & 0.44 & & & Gonzales \& Quinones (2000) \\
\hline Haploscoloplos sp. & 15 & en & 0 & 6.6 & 8.5 & & & & Gonzales \& Quinones (2000) \\
\hline Aricidea pigmentata & 40 & en & 0 & 1.8 & 3.0 & 2.49 & & & Gonzales \& Quinones (2000) \\
\hline Paraprionospio pinnata & 40 & en & 0.17 & 5.2 & 8.8 & & & & Gonzales \& Quinones (2000) \\
\hline \multicolumn{10}{|l|}{ Shallow water } \\
\hline Arenicola marina & - & bw & 0.2 & 99.0 & 10.5 & 0 & & & Siegmund et al. (1985) \\
\hline Glycera convolute & - & en & 0 & 171.4 & 51.9 & 0 & & & Siegmund \& Grieshaber (unpubl.) \\
\hline Nephtys hombergi & - & bw & 0 & 50.3 & 44.2 & 0 & & & Schöttler (1982) \\
\hline Nereis diversicolor & - & en & 48.8 & 0 & 0 & 0 & & & Schöttler (pers. comm.) \\
\hline Nereis virens & - & bw & 35 & 2 & 4 & 0 & 0 & 3.6 & Rinke \& Lee (unpubl. data) \\
\hline Scoloplos armiger & - & en & 0.8 & 73.8 & 96.7 & 0 & 0 & & Schöttler \& Grieshaber (1988) \\
\hline
\end{tabular}

both paralvinellids, with $1.03 \pm 0.47 \mu \mathrm{mol} \mathrm{g} \mathrm{min}^{-1}$ (mean $\pm \mathrm{SD}_{i} \mathrm{~N}=18$ ) and $1.31 \pm 0.35 \mu \mathrm{mol} \mathrm{g} \mathrm{min}^{-1}$ (mean $\pm \mathrm{SD}_{i} \mathrm{~N}=22$ ), respectively, compared to the high activities of ALPDH and SDH. SDH in the body wall showed the highest observed enzyme activity, with $44.84 \pm 10.86 \mu \mathrm{mol} \mathrm{g}^{-1} \mathrm{~min}^{-1}$ (mean $\pm \mathrm{SD}_{;} \mathrm{N}=18$ ) for $P$. sulfincola and $41.90 \pm 8.90 \mu \mathrm{mol} \mathrm{g} \mathrm{g}^{-1} \mathrm{~min}^{-1}$ (mean $\pm \mathrm{SD}_{i} \mathrm{~N}=21$ ) for $P$. palmiformis. Activities of the

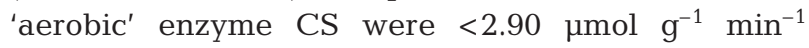
(Fig. 1a, b, Table 2).

Branchiae, compared to body wall, homogenates exhibited significantly higher LDH activity $(1.24 \pm$ $0.46 \mu \mathrm{mol} \mathrm{g}{ }^{-1} \mathrm{~min}^{-1}$ [mean $\pm \mathrm{SD} ; \mathrm{N}=17 ; \mathrm{p}<0.02$ ]) for Paralvinella sulfincola and slightly higher LDH activity for $P$. palmiformis $\left(1.51 \pm 0.33 \mu \mathrm{mol} \mathrm{g}{ }^{-1} \mathrm{~min}^{-1}\right.$ [mean \pm $\left.\left.\mathrm{SD}_{i} \mathrm{~N}=21 ; \mathrm{p}<0.07\right]\right)$. The ALPDH and SDH levels in the branchiae were significantly lower than in the body wall for both paralvinellids, with a maximum of $1.33 \pm 1.10 \mu \mathrm{mol} \mathrm{g}^{-1} \mathrm{~min}^{-1}$ (mean $\pm \mathrm{SD} ; \mathrm{N}=18$ ). Activities of CS differed significantly and were about 2 times higher in $P$. palmiformis branchiae $(\mathrm{N}=17 ; \mathrm{p}<0.00)$ and $>3$ times higher in $P$. sulfincola branchiae $(\mathrm{N}=18$; $\mathrm{p}<0.00$ ) than in body tissue (Fig. 1c, d, Table 2). No activity of $\mathrm{ODH}$ or TDH could be detected in paralvinellid homogenates of the body wall or branchiae.

Comparing enzyme activities between both paralvinellids, Paralvinella palmiformis exhibited higher activities of the anaerobic enzymes LDH in the body wall $(\mathrm{N}=18 ; \mathrm{p}<0.03)$ and branchiae $(\mathrm{N}=17 ; \mathrm{p}<0.03)$, as well as ALPDH $(\mathrm{N}=17$; $\mathrm{p}<0.02)$ and $\mathrm{SDH}(\mathrm{N}=17$; $\mathrm{p}<0.05$ ) in the branchiae versus the values in P. sulfincola (Table 2). Activities of the aerobic enzyme CS were significantly higher in the $P$. sulfincola body wall $(\mathrm{N}=18 ; \mathrm{p}<0.01)$ and branchiae $(\mathrm{N}=17 ; \mathrm{p}<0.00)$ compared to those of $P$. palmiformis (Fig. 1).

Some specimens were kept for up to $120 \mathrm{~h}$ under in situ pressure and supplied with air-saturated seawater. ALPDH and SDH enzyme activity levels of Paralvinella palmiformis body wall homogenates remained within the range of freshly collected specimens during the 
Table 3. Paralvinella palmiformis. Enzyme activities $\left(\mu \mathrm{mol} \mathrm{g} \mathrm{g}^{-1} \mathrm{~min}^{-1}\right.$ ) of body wall homogenates after being maintained for several days in high-pressure chambers at $5{ }^{\circ} \mathrm{C}$ supplied with air-saturated seawater, in comparison to freshly collected specimens. LDH: lactate dehydrogenase; ALPDH: alanopine dehydrogenase; SDH: strombine dehydrogenase

\begin{tabular}{|c|c|c|c|c|}
\hline Treatment & $\mathrm{N}$ & $\mathrm{LDH}$ & ALPDH & $\mathrm{SDH}$ \\
\hline \multicolumn{5}{|c|}{ Freshly collected } \\
\hline Mean \pm SD & 18 & $1.31 \pm 0.35$ & $33.71 \pm 6.38$ & $41.90 \pm 8.90$ \\
\hline Min. & 18 & 0.84 & 23.48 & 23.01 \\
\hline Max. & 18 & 2.05 & 49.47 & 56.43 \\
\hline \multicolumn{5}{|c|}{ Pressure chamber $24 \mathrm{~h}$} \\
\hline Specimen 1 & & 1.84 & 49.29 & 52.90 \\
\hline Specimen 2 & & 1.62 & 39.44 & 43.60 \\
\hline \multicolumn{5}{|c|}{ Pressure chamber $96 \mathrm{~h}$} \\
\hline Specimen 3 & & 1.16 & 34.86 & 39.98 \\
\hline Specimen 4 & & 1.30 & 41.86 & 48.69 \\
\hline \multicolumn{5}{|c|}{ Pressure chamber $120 \mathrm{~h}$} \\
\hline Specimen 5 & & 0.47 & 28.51 & 36.72 \\
\hline
\end{tabular}

experiment (Table 3). Only LDH enzyme activities dropped to less than half the values of freshly collected specimens after $120 \mathrm{~h}$ of incubation (Table 3 ).

Whole specimen homogenates of hydrocarbon seep polychaetes showed comparatively low overall enzyme activities, except for LDH activities of some specimens (Table 2). Within specimens belonging to the families Dorvellidae (seep dorvellid Ophryotrocha platykephale) and Ampharetidae (ampharetid) activity of SDH was the highest. In contrast the cold seep nereid homogenates revealed a predominance of LDH activity.

\section{Thermal stability}

In heat stability experiments LDH was the most heat stable enzyme, with activity about $1 \mu \mathrm{mol} \mathrm{g}^{-1} \mathrm{~min}^{-1}$ following incubations at $60^{\circ} \mathrm{C}$ in both paralvinellid species (Fig. 2c, d). A non-significant increase in LDH activity could be observed in branchiae homogenates of Paralvinella sulfincola after exposures between 40 and $55^{\circ} \mathrm{C}$. ALPDH and SDH enzymes in the body wall of $P$. sulfincola decreased slightly after being exposed to $40^{\circ} \mathrm{C}$ and above, and activity ceased at $55^{\circ} \mathrm{C}$. Enzyme activities of ALPDH and SDH dropped to zero at $45^{\circ} \mathrm{C}$ in $P$. palmiformis body wall homogenates (Fig. 2a, b).

CS activities in the branchiae and body wall of Paralvinella sulfincola remained constant in experiments up to $50^{\circ} \mathrm{C}$, dropped to very low levels after changing temperature to $55^{\circ} \mathrm{C}$, and were undetectable after $60^{\circ} \mathrm{C}$ exposures (Fig. 2e). The activities of CS in $P$. palmiformis already decreased to low levels after exposure to $45^{\circ} \mathrm{C}$ and were no longer detectable after $50^{\circ} \mathrm{C}$ treatments.

\section{Temperature shock experiments}

Paralvinellids were kept in pressure chambers, and their behavior was observed during the time course of heating and cooling. At elevated temperatures, paralvinellids increased their movement. Death was usually accompanied by spasms and/or bleeding, with no movement following cooling and reheating. Most Paralvinella palmiformis specimens did not survive temperatures $>40^{\circ} \mathrm{C}$, and temperatures $>47^{\circ} \mathrm{C}$ were lethal in all heat shock experiments (Fig. 3). P. sulfincola frequently survived temperatures $>50^{\circ} \mathrm{C}_{i}$ and a few specimens survived temperature of $60^{\circ} \mathrm{C}$, whereas $63^{\circ} \mathrm{C}$ was lethal. Enzyme activities in body wall homogenates of $P$. sulfincola specimens surviving $60^{\circ} \mathrm{C}$ were 22.62 and $29.30 \mu \mathrm{mol}$ $\mathrm{g}^{-1} \mathrm{~min}^{-1}$ for ALPDH and SDH, respectively (Table 4). Additionally, enzyme activities in body wall homogenates of $P$. sulfincola specimens exposed to $60^{\circ} \mathrm{C}$ starting from $2{ }^{\circ} \mathrm{C}$ were almost completely lost, with ALPDH showing the highest levels of $0.52 \mu \mathrm{mol} \mathrm{g}^{-1}$ $\min ^{-1}$ (Table 4).

\section{Glycogen}

Mean glycogen levels of body walls of both paralvinellid species were $<2.9 \mathrm{mg} \mathrm{g}^{-1}$ (Table 5), and no glycogen could be detected in the branchiae. Free glucose could be found in the body wall at $2.8 \mathrm{mg} \mathrm{g}^{-1}$ in Paravinella sulfincola and $2.1 \mathrm{mg} \mathrm{g}^{-1}$ in P. palmiformis, and at lower levels of 1.07 and $1.71 \mathrm{mg} \mathrm{g}^{-1}$, respectively, in the branchiae of both observed species.

\section{DISCUSSION}

\section{Aerobic and anaerobic metabolism}

Aerobic and anaerobic enzyme activities in paralvinellids

Paralvinella sulfincola and P. palmiformis inhabit different niches on hydrothermal vent chimneys. In general, $P$. sulfincola inhabits higher temperature environments, with concomitant high sulfide and low oxygen. P. palmiformis, on the other hand, colonizes diffuse vent flow habitats, with lower temperatures and sulfide values (Sarrazin et al. 1999) and therefore higher oxygen concentrations. Given the different environ- 
(a) P. sulfincola ALPDH \& SDH

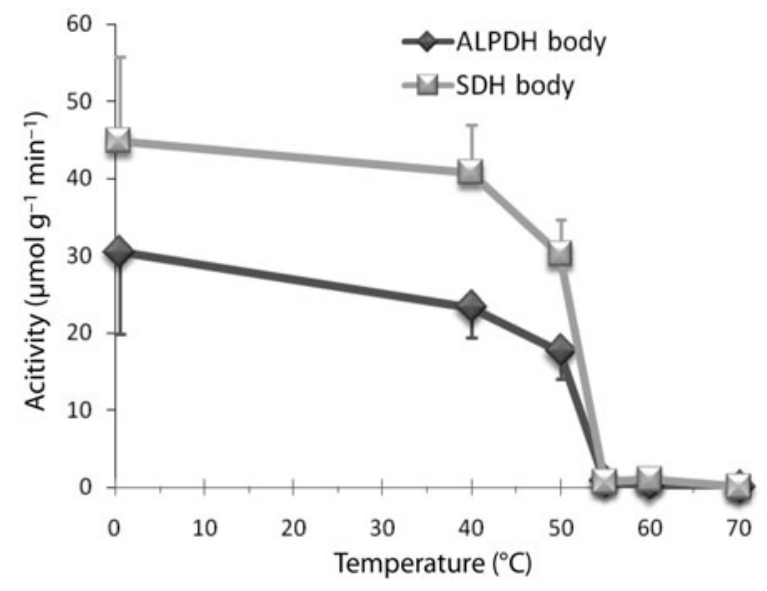

(c) P. sulfincola LDH

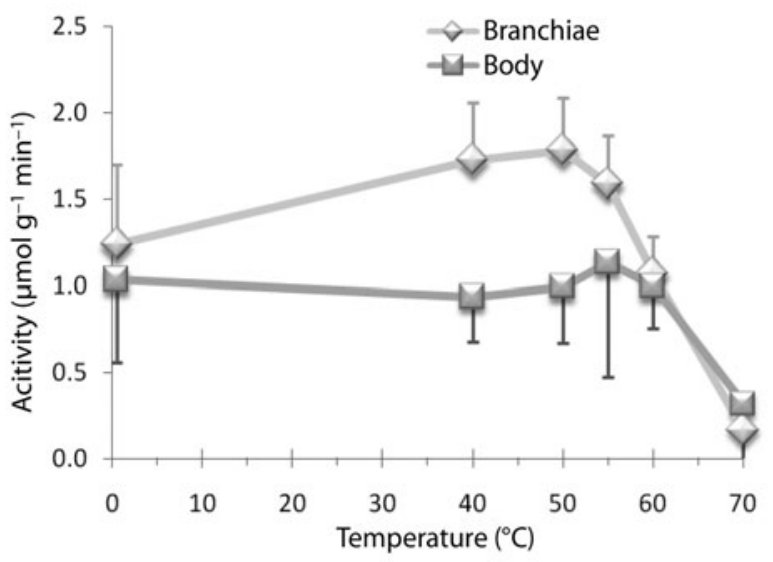

(e) P. sulfincola citrate synthase

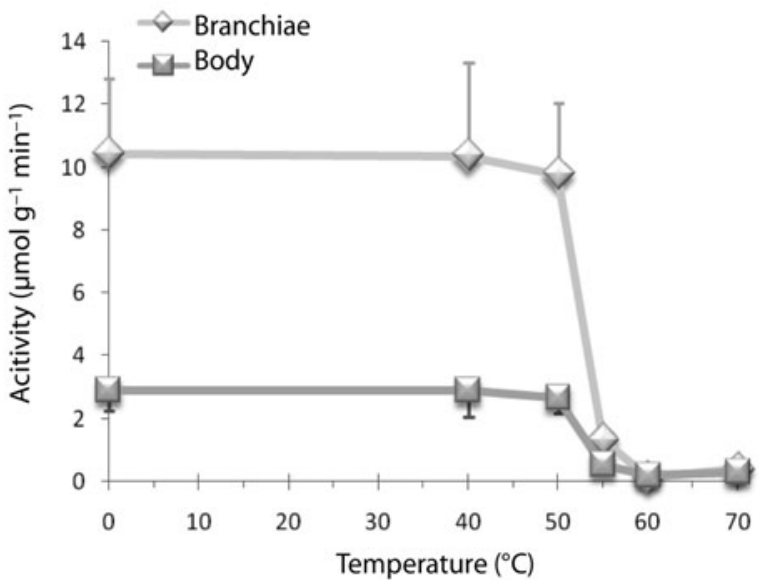

(b) P. palmiformis ALPDH \& SDH

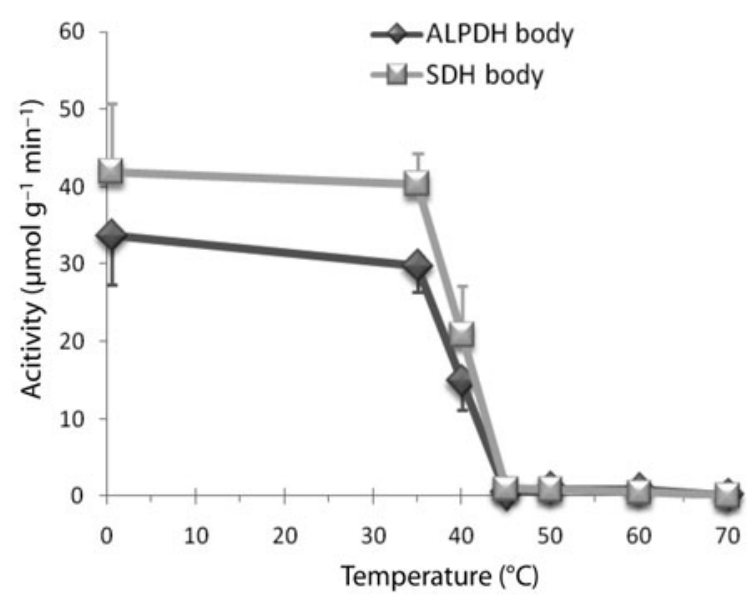

(d) P. palmiformis LDH

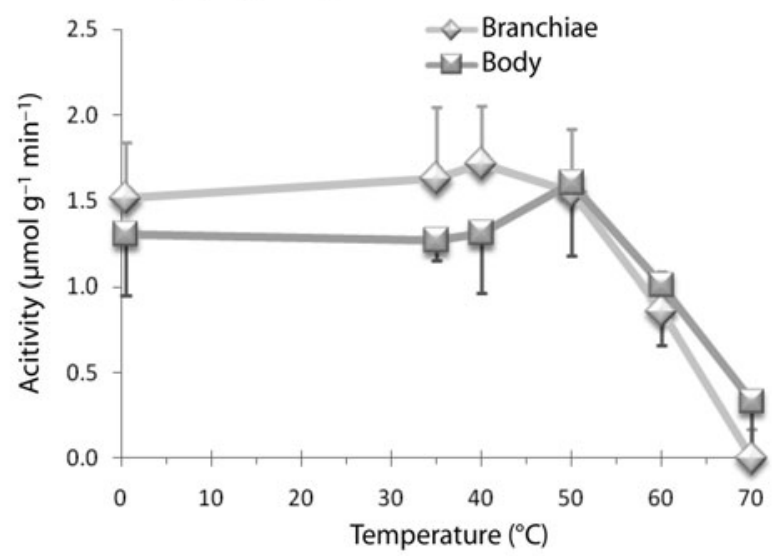

(f) P. palmiformis citrate synthase

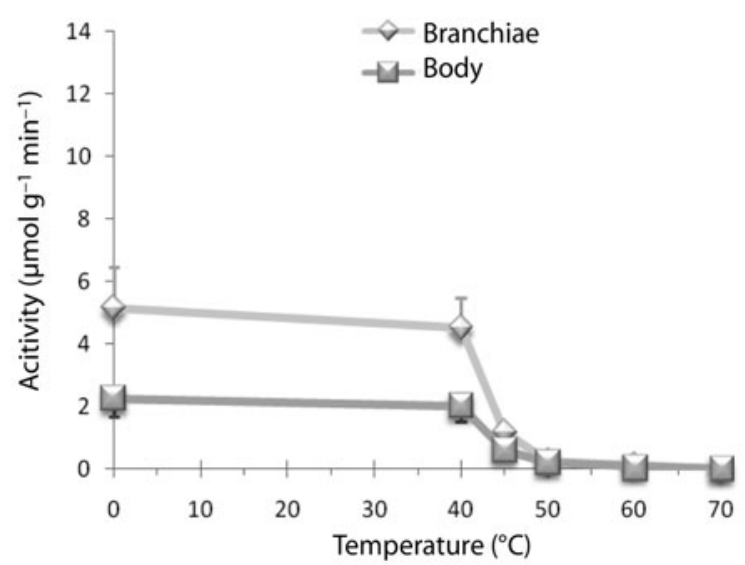

Fig. 2. Paralvinella sulfincola, Paralvinella palmiformis. Enzyme activities of $(\mathrm{a}, \mathrm{c}, \mathrm{e}) P$. sulfincola and $(\mathrm{b}, \mathrm{d}, \mathrm{f}) P$. palmiformis homogenates after incubation at elevated temperature for 15 min. (a, b) ALPDH and SDH activities in the body wall. (c, d) LDH activities in the branchiae (gills) and whole body. (e, f) CS activities in the branchiae (gills) and whole body. Note the different scales on the $y$-axis. Enzyme definitions as in Fig. 1 


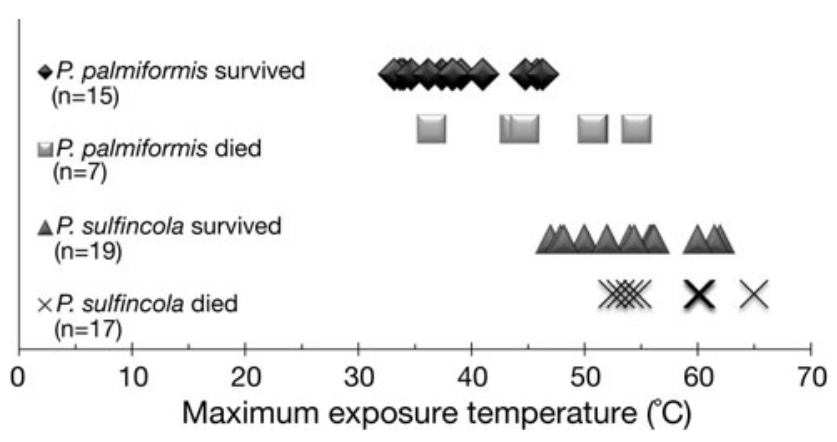

Fig. 3. Paralvinella sulfincola, Paralvinella palmiformis. Temperature shock experiments of paralvinellids in pressure chambers. Each data point refers to a single trial in which the specimen either died or survived. Survival was determined by movement being exhibited in the heating/cooling cycle that followed the trial mental conditions encountered in situ, $P$. sulfincola might be expected to exhibit higher activities of anaerobic enzyme activities and a reduced capacity for aerobic respiration, as well as a higher ratio of anaerobic to aerobic capacity compared to P. palmiformis. However, the results from the present study do not support this. For example, aerobic CS activities are similar, but significantly higher $(\mathrm{p}<0.01 ; \mathrm{p}<0.00)$ in the body wall and 2-fold higher in the branchiae of $P$. sulfincola compared to $P$. palmiformis. Also, compared to the enzyme activities of branchial homogenates of other hot vent polychaetes such as Paralvinella grasslei (Alvinellidae; Marie et al. 2006) and Riftia pachyptila (Siboglinidae; Powell \& Somero 1986), the levels we observed for $P$. sulfincola were the highest recorded. Thus, the patterns of anaerobic respiratory enzymes in the 2 species do not suggest a greater reliance on anaerobic pathways in $P$. sulfincola. On the contrary, $P$. palmiformis shows a slightly but significantly higher activity of anaerobic enzymes ( $\mathrm{LDH}, \mathrm{ALPD}, \mathrm{SDH})$ in the branchiae, as well as of LDH in the body wall, than does $P$. sulfincola. One explanation would be that, while the environments do differ between the species, they are not sufficiently different to require different metabolic adjustments with respect to anaerobic and aerobic respiration. It may be the case that both species are well adapted to tolerate hypoxic conditions and temporary anoxia. Unfortunately, very few oxygen measurements have been made in these or other vent environments. Previous work has also shown that a clear pattern of enzyme activities of vent invertebrates reflecting their different niches at hydrothermal vents could not be established (Hand \& Somero 1983).

\section{Distribution of enzymes in body tissues}

Given the spatial characteristics of steep thermal gradients in hydrothermal vent environments, it is possible that different physicochemical conditions are encountered by different tissues in alvinellid worms (comprising the genera Alvinella and Paralvinella). For example, Cary (Cary et al. 1998, Di Meo-Savoie et al. 2004) has shown a thermal gradient inside the tube along 
the body of A. pompejana. In situ observations of paralvinellids show that the posterior portion of the body is generally within the mucous tube, which they secrete and attach to the mineral substratum (Tunnicliffe et al. 1993). Behavioral studies showed that $P$. sulfincola spends most of its time in a position in which the branchiae are located outside the tube, whereas the body remains inside (Grelon et al. 2006). Individuals can extend their body several fold compared to their contracted length when grazing on the substrate. In terms of enzyme activities, both paralvinellid species show a somewhat similar and distinct pattern for body wall and branchial tissue, respectively. According to our results the branchiae (gills) may favor aerobic metabolic pathways. The levels of the aerobic enzyme CS in the paralvinellid branchiae were much higher than those in the body wall (Fig. 1). Similarly, CS activities have been shown to be more than twice as high in the branchiae as in the body wall of $P$. grasslei, which lives at the East Pacific Rise (Marie et al. 2006; our Table 2). In contrast, the anaerobic enzyme activities in the branchiae of $P$. sulfincola and $P$. palmiformis are up to 20 times lower than those in the body wall (Fig. 1). Thus, the branchiae can be identified as the body part of hot vent paralvinellids in which aerobic metabolism may dominate.

Paralvinellids may be able to place their branchiae into water containing higher oxygen levels, and are likely to enhance gas exchange from low environmental concentrations through the motion of the branchiae during exploration and sweeping behaviors as has been suggested recently (Grelon et al. 2006). The branchiae are essential for oxygen uptake of hydrothermal vent polychaetes, which are known to possess increased gill surface areas and very short diffusion distances from surface to blood vessels to maximize oxygen extraction (see Hourdez \& Lallier 2007). A part of the acquired oxygen is probably transferred to the circulatory system, since alvinellids possess extracellular hemoglobin in the blood (Toulmond et al. 1990). Studies of alvinellids have suggested that, in Alvinella pompejana, oxygenated blood from the branchiae is carried to a capillary network where it exchanges gas with intracellular hemoglobin (Jouin-Toulmond et al. 1996) and continues its flow to supply the cerebral ganglion with oxygen (Hourdez \& Lallier 2007). Our results indicate that branchial tissues appear to rely primarily on aerobic respiration.

While the muscles of the alvinellid body, which are major components of the body wall, would be perfused by the circulatory system, energy production in the body wall of Paralvinella sulfincola and P. palmiformis seems to rely extensively on anaerobic pathways. Levels of the aerobic enzyme CS in the body wall of both paralvinellids were about 2 times lower than in the branchiae. These results are in accordance with earlier findings that muscles of a number of marine invertebrates show very low CS activity and should therefore obtain little energy from aerobic metabolism (Alp et al. 1976; our Table 2). In addition, the activity of the anaerobic enzymes ALPDH and SDH was about 20 times higher in the body wall than in the branchiae. The favoring of anaerobic pathways may be due to reduced oxygen availability or utilization of anaerobic pathways for rapid muscle contraction. However, low oxygen may not be an important factor, since levels of anaerobic enzyme expression do not appear to be dependent on environmental hypoxia or high temperature.

In experiments, Paralvinella palmiformis were kept for up to $120 \mathrm{~h}$ in high-pressure aquaria with oxygensaturated seawater at $5^{\circ} \mathrm{C}$. Enzyme activities of body wall homogenates remained within the range of those for freshly collected specimens (Table 3). Thus, our results indicate that the worms continuously express these enzymes, at least up to $120 \mathrm{~h}(5 \mathrm{~d})$. Therefore, one could speculate that the observed levels of anaerobic enzyme activities (Fig. 1, Table 2) are permanently maintained rather than the result of hypoxia in the environment prior to collection. Concerning the maintenance of $P$. palmiformis, a harmful or even lethal effect of exposing living specimens to air-saturated surface seawater, as has been suggested for Alvinella pompejana and demonstrated for P. grasslei (Marie et al. 2006), was not observed in our experiments. However, our sample size was small (Table 3), and future experiments are may needed to gain more insights into enzyme levels at different physicochemical conditions.

\section{Comparison of paralvinellids with cold seep and shallow water species}

Given the unusual environment inhabited by paralvinellid worms, a comparison of their aerobic and anaerobic enzyme activities with those of other polychaetes living in shallow waters, as well as elsewhere in the deep sea, is of interest. Most polychaetes preferentially utilize opine dehydrogenases to regenerate $\mathrm{NAD}^{+}$during anaerobic fermentation (Table 2). Polychaetes of the genus Nereis are a major exception; like vertebrates, they utilize LDH rather than opine dehydrogenases. Paralvinellids exhibited high activity of ALPDH and SDH, negligible activity of LDH, as well as no ODH or TDH activity in body wall tissues (Table 2). This is similar to the pattern observed in non-nereid polychaetes from shallow water. Consequently, anaerobic pathways in paralvinellids appear to be similar to those in other polychaetes. Our results are in accor- 
dance with previous findings, showing that the body tissues of vent animals and related shallow-living marine species have similar types of energy metabolism pathways, and similar potentials for flux through these pathways (Hand \& Somero 1983). A comparison of enzyme activities of the branchiae (gills) of Paralvinella sulfincola and P. palmiformis with littoral species is, however, not possible, since the latter are usually devoid of gills.

In general, the levels of opine dehydrogenases in paralvinellids are similar or lower than those in shallow water species. Such results indicate that these pathways may be less important for paralvinellids than for polychaetes living in reducing sediments. Aerobic enzyme (CS) activities were not particularly high, so paralvinellids may not have high metabolic rates. This suggests that there is some oxygen limitation that would favor lower metabolic rates, but an absence of chronic anoxia, which would favor elevated opine dehydrogenase activity. This appears likely, since paralvinellids live on hard substrates in contact with overlying seawater that is mixed with vent fluids, resulting in a complex and rapidly changing flow regime. While there are undoubtedly hypoxic to anoxic conditions present in the vent environment, these conditions may be less severe than those faced by infauna in reducing sediments.

Also comparing shallow water with deep sea polychaetes, a possible impact of high hydrostatic pressure on in situ enzyme activities cannot be ruled out. Proteins are surrounded by water molecules forming the protein hydration layer. An unfolded protein packs water molecules in the hydration layer at a higher density than that of cell bulk water. Upon folding or binding, a net expansion occurs as water molecules are released into the bulk water. Thus, hydrostatic pressure has the ability to inhibit protein folding and ligand binding (Yancey 2001, 2005, Yancey et al. 2002). This negative effect seems to be counteracted by organic osmolytes, small solutes that also stabilize macromolecules. Whereas the osmolyte compositions and levels of paralvinellids still await analysis, high amounts of hypotaurine have been found in another hydrothermal vent polychaete, the tubeworm Riftia pachyptila (Yancey 2005).

Cold seep polychaetes showed the lowest overall activities of aerobic and anaerobic enzymes in our dataset. Whereas hot vent and shallow water polychaetes show high enzyme activities for at least one of the investigated anaerobic enzymes, seep polychaetes exhibit low maximum enzyme activities, not higher than $4.40 \mu \mathrm{mol} \mathrm{g}{ }^{-1} \mathrm{~min}^{-1}$ (Table 2). The anaerobic enzyme levels were similar to those reported for some continental shelf deep sea species sampled down to $121 \mathrm{~m}$ depth (Table 2). A comparison of anaerobic enzyme activity levels in cold seep species reveals that taxonomic similarity is more important than habitatspecific environmental conditions. For example, the 'cold seep nereid' does not show a preferential use of ALPDH, like the other examined seep species, but features LDH as its major anaerobic pathway, like its shallow water relatives. The hydrocarbon seeps investigated so far at the eastern Pacific margin revealed high porewater sulfide concentrations (up to $20 \mathrm{mM}$ ) and almost no oxygen penetration of the sediments (Levin et al. 2003), thus suggesting that the anaerobic enzyme levels of cold seep polychaetes are similar or even higher than those of shallow water species. However, our results show low levels of opine dehydrogenase activity in cold seep polychaetes, whereby low temperature may be a major factor influencing enzyme activity. While the range of temperatures for shallow-living polychaetes and vent paralvinellids overlap, the low temperatures at cold seeps are much lower (in the range from 2 to $5^{\circ} \mathrm{C}$ ). These observed overall low enzyme activities of cold seep polychaetes dwelling in a spatially and temporally very stable habitat suggest that cold seeps favor slow growth and, thus, low metabolic activity, as observed for other hydrocarbon seep polychaetes (Fisher et al. 1997).

\section{Thermal tolerance and enzyme thermal stability in paralvinellids}

\section{Temperature shock experiments}

Paralvinella palmiformis occasionally survived short time periods at temperatures $>40^{\circ} \mathrm{C}$. $P$. sulfincola frequently survived temperatures $>50^{\circ} \mathrm{C}$, and a few specimens exhibited activity up to $60^{\circ} \mathrm{C}$, whereas $63^{\circ} \mathrm{C}$ was lethal in all cases. Previous studies had investigated lethal temperatures in response to slow $\left(10^{\circ} \mathrm{C} \mathrm{h}^{-1}\right)$ increases in temperatures (Lee 2003) or temperature preference in a gradient (Girguis \& Lee 2006). Initially, we speculated that paralvinellids might be able to tolerate higher temperatures if they are exposed to rapid increases in temperature and thus an overall shorter exposure to elevated temperatures. Surprisingly this was not the case. The lethal temperatures in our experiments, when increasing the temperature to about $40^{\circ} \mathrm{C}$ in 5 min or less, corresponded well with those observed previously in response to slow increases in temperature (Lee 2003).

Unfortunately, due to the difficulty of collecting living deep-sea specimens and maintaining them under high-pressure conditions, only limited in vivo thermal data for alvinellids other than Paralvinella sulfincola and $P$. palmiformis are available. A recent study revealed that $P$. grasslei survives rapid temperature 
increases $\left(3^{\circ} \mathrm{C} \mathrm{min}^{-1}\right)$ to $30^{\circ} \mathrm{C}$ for at least $30 \mathrm{~min}$, followed by a delayed upregulation of expression of heat shock proteins (Cottin et al. 2008). These proteins are expressed when animals are exposed to stressful but non-lethal temperatures and are capable of destroying or repairing damaged proteins (Parsell \& Lindquist 1993).

In addition, according to our data, lethal temperatures in thermally shocked animals resulted in near inactivation of some enzymatic pathways. Specimens of Paralvinella sulfincola were analyzed for enzyme activity after a $60^{\circ} \mathrm{C}$ temperature shock. Our results showed that enzyme activities of heat-shocked worms (10 to $20^{\circ} \mathrm{C}$ starting temperature), dropped close to (ALPDH) or even below (SDH) the lowest values found in freshly collected specimens (Table 4). Shocking worms from an initial temperature of $2^{\circ} \mathrm{C}$ resulted in the complete inhibition of enzyme activity (Table 4 ). Thus, we conclude that short exposures to temperatures of $60^{\circ} \mathrm{C}$ and above have a negative effect on anaerobic opine dehydrogenase enzyme activities in vivo. Our results suggest that the magnitude of the temperature change is an important factor in limiting enzymatic pathways and thus the thermal tolerance of $P$. sulfincola. In contrast, ALPDH and SDH enzyme activities in $P$. sulfincola tissue extracts are inactivated at a lower temperature $\left(55^{\circ} \mathrm{C}\right)$. This difference in enzymatic thermal tolerance between the exposure of living worms and tissue homogenates to temperature increases might be explained by a heat-buffering effect of the intact polychaete body or protective intracellular factors. However, the difference in the heating time frames (5 versus $15 \mathrm{~min}$ ) allows no direct comparison, and further experiments are needed to evaluate heat protection mechanisms in paralvinellids.

\section{Enzyme thermal stability}

Thermal stability experiments of in vitro enzyme activities showed stability after exposure to elevated temperatures; except for $\mathrm{LDH}$, these results correlated with the preferred temperatures of living paralvinellids. Anaerobic opine dehydrogenase enzymes in the body wall of Paralvinella sulfincola still showed 58 and $67 \%$ activity for ALPDH and SDH, respectively, after being exposed to $50^{\circ} \mathrm{C}$, until activity was inactivated at $55^{\circ} \mathrm{C}$. These data are in accordance with results from previous experiments, in which $P$. sulfincola preferred temperatures between 40 and $50^{\circ} \mathrm{C}$ (Girguis \& Lee 2006) and died at temperatures $>50$ to $56^{\circ} \mathrm{C}$ (Lee 2003). ALPDH and SDH enzyme activities dropped to zero at $45^{\circ} \mathrm{C}$ in $P$. palmiformis body wall homogenates, correlating with previous findings that this species avoids temperatures $>35^{\circ} \mathrm{C}$ (Girguis \& Lee 2006) and dies at temperatures $>40^{\circ} \mathrm{C}$ (Lee 2003). The differences in thermal stability between the 2 paralvinellids are also in good agreement with a previous study of alvinellid enzymes in which species living on the walls of hydrothermal vent chimneys display more thermoresistant allozymes than species dwelling in 'cooler' conditions, such as diffuse venting areas (Jollivet et al. 1995).

LDH is known for heat stability in shallow water animals that seem to derive no direct advantage from this feature, as shown for different species of porcelain crabs (Stillman \& Somero 2000). In paralvinellids, LDH exhibited high thermal stability, with an activity of about $1 \mu \mathrm{mol} \mathrm{g}{ }^{-1} \mathrm{~min}^{-1}$ up to $60^{\circ} \mathrm{C}$ in both species. According to Stillman \& Somero (2000), LDH stability does not mark an adaptive response to current thermal habitats, but is related to the properties of the LDH molecule itself (intrinsic stability) and to the effects of extrinsic proteins.

Interestingly, in Paralvinella sulfincola, aerobic enzymes that exhibited high activity in the branchiae showed higher thermal stability than anaerobic enzymes that were mostly present in the body wall (Fig. 2). After exposure to $50^{\circ} \mathrm{C}, \mathrm{ALPDH}$ and $\mathrm{SDH}$ in the body wall showed residual activities of 57.95 and $67.33 \%$, respectively, whereas the activity of CS in the branchiae remained at $93.67 \%$ of that in homogenates not exposed to elevated temperature. This could be due to differences in the intrinsic thermostabilities of aerobic versus anaerobic enzymes. While no data on the structural thermostabilities of opine dehydrogenases are available, CS is known to also function in hyperthermophilic organisms, such as the Archaeum $P y-$ rococcus furiosus (which exhibits growth at $100^{\circ} \mathrm{C}$ ). In this case, the thermostability of the whole enzyme is mainly determined by intrinsic structures, in particular, by the origin of the large, inter-subunit domain, whereas the dependence of catalytic activity on temperature is a function of the small domain (Arnott et al. 2000). Alternatively, one could speculate that the body wall encounters lower temperatures than the anterior part of the worm including branchiae. For $P$. sulfincola it is known that the polychaete spends most of its time in a position in which the branchiae are located at the tube entrance or outside the tube, whereas the body remains totally or partially inside the tube (Grelon et al. 2006). Thus, the paralvinellid tube could possibly aid in protecting the body from approaching hot water gusts caused by the highly complex vent flow regimes. A temperature gradient present over the length of the body, as suggested for Alvinella pompejana (Cary et al. 1998), could possibly also apply to $P$. sulfincola, only spatially reversed. A. pompejana exhibits a relatively impermeable and solid tube, which is vertically embedded in an extracellular matrix, overlaid by a cooler 
vent fluid-seawater mixing layer. The distal parts of the tubes extrude into this layer (Le Bris et al. 2005). Thus, the gills of Pompeii worms experience lower temperatures than the rest of the body, except when they are completely retracted into the tube. Paralvinellids, such as $P$. sulfincola, only build a thin mucus tube on the actively growing portions of sulfide mineral chimneys (Grelon et al. 2006). No data on the physicochemical micro-environments of $P$. sulfincola are available thus far; however, our idea of a possible temperature gradient is further supported by our observations that paralvinellids always orient their head towards the hotter area in gradient pressure chambers.

\section{Glycogen storage}

Glycogen levels in both paralvinellid species were below levels recorded for inter- and subtidal polychaetes (Table 5). Applying the positive correlation of glycogen concentrations with the risk of anoxia in their natural habitat, which was found for shallow water polychaetes (Von Brandt 1927, Augenfeld 1978), the low glycogen content would suggest that Paralvinella sulfincola and $P$. palmiformis are not frequently exposed to a high risk of anoxia. Alternatively, a novel explanation may be that glycogen reserves are less important if paralvinellids can obtain carbon through feeding under anoxic conditions. Periods of low or no oxygen for intertidal shallow water polychaetes occur mainly during low tides, when most worm burrows are emersed for up to several hours (Augenfeld 1978). During this time the worms rely on anaerobic metabolism and do not feed; thus, they are required to utilize stored glycogen as an energy source. The oxygen concentrations of paralvinellid microhabitats from hydrothermal vents are not well characterized, mostly due to the complex fluid mixing and technical difficulties involved in deep sea oxygen measurements. However, observations of animals within centimeters of $350^{\circ} \mathrm{C}$ water suggest that they are likely to commonly encounter periods of elevated temperatures and anoxic water (Tunnicliffe et al. 1993). Behavioral studies of $P$. sulfincola show that they spend $34 \%$ of their time involved in behavioral patterns associated with the search for food (Grelon et al. 2006). The worm remains partially within its tube and feeds by grazing on microbial biofilms on the mineral substratum nearby (Tunnicliffe 1988, Morineaux et al. 2002) and on its tube (Grelon et al. 2006). Anoxic conditions are likely to exist while feeding behavior is observed. Water temperatures, which are generally lower for shallow water species $\left(8\right.$ to $12^{\circ} \mathrm{C}$ for the species listed in Table 5; Augenfeld 1978) than for the observed hydrothermal vent species, probably also influence metabolic activities and thus the required glycogen amount. Therefore, paralvinellids, which should have a higher glycogen demand and which showed lower glycogen storage compared to shallow water polychaetes, are presumably also able to feed (acquire energy) during anoxic conditions.

\section{Conclusions}

By investigating Paralvinella sulfincola and P. palmiformis we verified aerobic and anaerobic enzyme activities. Among the anaerobic enzymes, opine dehydrogenases showed higher levels than LDH. Although both paralvinellid species are known to dwell in habitats with different abiotic conditions, our results suggest that the environments are not sufficiently different to clearly require dissimilar enzymatic compositions. Our results also emphasize the importance of analyzing and comparing different body parts and tissues of invertebrates, whenever possible, since enzyme activities strongly vary among them. In our investigation, we could attribute differences to a predominance of aerobic pathways in the branchiae and a preference for anaerobic glycolysis in the body wall muscles. Incubation experiments in high-pressure chambers indicate that paralvinellids continuously express anaerobic enzymes, and the observed levels are not due to anoxia events prior to collection. Overall, vent polychaetes seem to have similar pathways and levels of energy metabolism to those found in shallow water polychaetes, although polychaetes from cold seeps showed the lowest observed enzyme activities, most likely due to their low temperature and stable habitat favoring slow growth. We detected a remarkable thermal tolerance in the enzymes studied, potentially enabling $P$. sulfincola and $P$. palmiformis to survive in their harsh environments. These thermal enzyme stabilities correlate, except for that of $\mathrm{LDH}$, with the preferred temperatures of living paralvinellids. Also, enzyme activities were found to be one of the parameters limiting the upper thermal tolerance in paralvinellids. According to our temperature shock experiments, the temperature change per unit time has a negligible effect, whereas the magnitude of temperature change has a very strong impact on paralvinellid metabolism. Glycogen storage levels of vent paralvinellids turned out to be very low compared to those of shallow water polychaetes, which we suggest is due to their ability to feed and, thus, to supplement their glucose supply even during anoxic conditions. However, extensive studies of alvinellids, preferably under carefully controlled in vitro conditions, are needed to gain more insight into these organisms coping with one of the harshest environments on earth. 
Acknowledgements. We thank the crew of the submersible 'Alvin' and the vessel 'Atlantis' for their support, and John Rutherford for machining. This project was funded by NSF OCE-0623554 (Ray Lee and Peter Girguis) and NSF OCE0425600 (Ray Lee).

\section{LITERATURE CITED}

Alp PR, Newsholme EA, Zammit VA (1976) Activities of citrate synthase and $\mathrm{NAD}^{+}$-linked and $\mathrm{NADP}^{+}$-linked isocitrate dehydrogenase in muscle from vertebrates and invertebrates. Biochem J 154:689-700

- Arndt C, Schiedek D, Felbeck H (1998) Metabolic responses of the hydrothermal vent tubeworm Riftia pachyptila to severe hypoxia. Mar Ecol Prog Ser 174:151-158

Arnott MA, Michael RA, Thompson CR, Hough DW, Danson MJ (2000) Thermostability and thermoactivity of citrate synthases from the thermophilic and hyperthermophilic Archaea, Thermoplasma acidophilum and Pyrococcus furiosus. J Mol Biol 304:657-668

Augenfeld JM (1978) Relation of habitat to glycogen concentration and glycogen synthetase in polychaetes. Mar Biol 48:57-62

Cary SC, Shank T, Stein J (1998) Worms bask in extreme temperatures. Nature 391:545-546

Chevaldonné P, Fisher CR, Childress JJ, Desbruyères D, Jollivet D, Zal F, Toulmond A (2000) Thermotolerance and the 'Pompeii worms'. Mar Ecol Prog Ser 208:293-295

Cottin D, Ravaux J, Leger N, Halary S, Toullec J-Y, Sarradin PM, Gaill F, Shillito B (2008) Thermal biology of the deepsea vent annelid Paralvinella grasslei: in vivo studies.. J Exp Biol 211:2196-2204

Dahlhoff E, Schneidemann S, Somero GN (1990) Pressuretemperature interactions on $\mathrm{M}_{4}$-lactate dehydrogenases from hydrothermal vent fishes: evidence for adaptation to elevated temperatures by the zoarcid Thermarces andersoni, but not the bythitid Bythites hollisi. Biol Bull 179:134-139

Dahlhoff E, O'Brien J, Somero GN, Vetter RD (1991) Temperature effects on mitochondria from hydrothermal vent invertebrates: evidence for adaptation to elevated and variable habitat temperatures. Physiol Zool 64:1490-1508

> Desbruyères $D$, Chevaldonné $P$, Alayse AM, Jollivet $D$ and others (1998) Biology and ecology of the 'Pompeii worm' (Alvinella pompejana Desbruyeres and Laubier), a normal dweller of an extreme deep-sea environment: a synthesis of current knowledge and recent developments. Deep Sea Res II 45:383-422

$>$ Di Meo-Savoie CA, Luther GW, Cary SC (2004) Physicochemical characterization of the microhabitat of the epibionts associated with Alvinella pompejana, a hydrothermal vent annelid. Geochim Cosmochim Acta 68:2055-2066

Fisher CR, Urcuyo I, Simpkins MA, Nix E (1997) Life in the slow lane: growth and longevity of cold-seep vestimentiferans. PSZN I: Mar Ecol 18:83-94

Gaill F, Wiedcmann H, Mann K, Kuhn K, Timpl R, Engel J (1991) Molecular characterization of cuticle and interstitial collagens from worms collected at deep sea hydrothermal vents. J Mol Biol 221:209-223

Girguis PR, Lee RW (2006) Thermal preference and tolerance of alvinellids. Science 312:231

> González RR, Quiñones RA (2000) Pyruvate oxidoreductases involved in glycolytic anaerobic metabolism of polychaetes from the continental shelf off Central-South Chile. Estuar Coast Shelf Sci 51:507-519

Grace MFL, Fletcher L, Powers SK, Hughes M, Coombes J
(1996) A comparison of maximal bioenergetic enzyme activities obtained with commonly used homogenization techniques. J Sports Med Phys Fitness 36:281-286

> Grelon D, Morineaux M, Desrosiers G, Juniper SK (2006) Feeding and territorial behavior of Paralvinella sulfincola, a polychaete worm at deep-sea hydrothermal vents of the Northeast Pacific Ocean. J Exp Mar Biol Ecol 329:174-186

Grieshaber MK, Völkel S (1998) Animal adaptations for tolerance and exploitation of poisonous sulfide. Annu Rev Physiol 60:33-53

> Grieshaber MK, Hardewig I, Kreutzer U, Pörtner HO (1994) Physiological and metabolic responses to hypoxia in invertebrates. Rev Physiol Biochem Pharmacol 125:43-147

> Hand SC, Somero GN (1983) Energy metabolism pathways of hydrothermal vent animals: adaptations to a food-rich and sulfide-rich deep-sea environment. Biol Bull 165:167-181

Hochachka PW, Somero GN (2002) Biochemical adaptation: mechanism and process in physiological evolution. Oxford University Press, New York

$>$ Hourdez SP, Lallier FO (2007) Adaptations to hypoxia in hydrothermal-vent and cold-seep invertebrates. Rev Environ Sci Biotechnol 6:143-159

Jollivet D, Desbruyères D, Ladrat C, Laubier L (1995) Evidence for differences in allozyme thermostability of deepsea hydrothermal vent polychaetes (Alvinellidae): a possible selection by habitat. Mar Ecol Prog Ser 123:125-136

Jouin-Toulmond C, Augustin D, Desbruyères D, Toulmond A (1996) The gas transfer system in alvinellids (Annelida, Polychaeta, Terebellida): anatomy and ultrastructure of the anterior circulatory system and characterization of a coelomic, intracellular haemoglobin. Cah Biol Mar 37: 135-151

Le Bris N, Zbinden M, Gaill F (2005) Processes controlling the physico-chemical micro-environments associated with Pompeii worms. Deep Sea Res I 52:1071-1083

> Lee RW (2003) Thermal tolerances of deep-sea hydrothermal vent animals from the Northeast Pacific. Biol Bull 205: 98-101

> Levin LA, Ziebis W, Mendoza GF, Growney VA and others (2003) Spatial heterogeneity of macrofauna at northern California methane seeps: influence of sulfide concentration and fluid flow. Mar Ecol Prog Ser 265:123-139

> Magenheim AJ, Gieskes JM (1992) Hydrothermal discharge and alteration in near-surface sediments form the Guaymas Basin Gulf of California. Geochim Cosmochim Acta 56:2329-2338

> Marie B, Genard B, Rees JF, Zal F (2006) Effect of ambient oxygen concentration on activities of enzymatic antioxidant defences and aerobic metabolism in the hydrothermal vent worm, Paralvinella grasslei. Mar Biol 150: $273-284$

> McMullin ER, Bergquist DC, Fisher CR (2000) Metazoans in extreme environments: adaptations of hydrothermal vent and hydrocarbon fauna. Gravit Space Biol Bull 13:13-23

Morineaux M, Grelon D, Juniper SK (2002) Nutritional resources and their utilisation in populations of the hydrothermal vent polychaete Paralvinella sulfincola on Axial Volcano, Juan de Fuca Ridge (Northeast Pacific). Cah Biol Mar 43:241-244

Parsell DA, Lindquist S (1993) The function of heat-shock proteins in stress tolerance: degradation and reactivation of damaged proteins. Annu Rev Genet 27:437-496

Passonneau JV, Lauderdale VR (1974) A comparison of three methods of glycogen measurement in tissues. Anal Biochem 60:405-412

$>$ Powell MA, Somero GN (1986) Adaptations to sulfide by hydrothermal vent animals: sites and mechanisms of 
detoxification and metabolism. Biol Bull 171:274-290

Sarrazin J, Juniper SK, Massoth G, Legendre P (1999) Physical and chemical factors influencing species distributions on hydrothermal sulfide edifices of the Juan de Fuca Ridge, northeast Pacific. Mar Ecol Prog Ser 190:89-112

Schöttler U (1982) An investigation on the anaerobic metabolism of Nephtys hombergii (Annelida: Polychaeta). Mar Biol 71:265-269

Schöttler U, Bennet EM (1991) Annelids. In: Bryant C (ed) Metazoan life without oxygen. Chapman \& Hall, London, p 165-185

Schöttler U, Grieshaber M (1988) Adaptation of the polychaete worm Scoloplos armiger to hypoxic conditions. Mar Biol 99:215-222

Siegmund B, Grieshaber M, Rejtze M, Zebe E (1985) Alanopine and strombine are end products of anaerobic glycolysis in the lugworm Arenicola marina L. (Annelida, Polychaeta). Comp Biochem Physiol 82B:337-345

Stillman JH, Somero GN (2000) A comparative analysis of the upper thermal tolerance limits of eastern Pacific porcelain crabs, genus Petrolisthes: influences of latitude, vertical zonation, acclimation, and phylogeny. Physiol Biochem Zool 73:200-208

Terwilliger NB, Terwilliger RC (1984) Hemoglobin from the 'Pompeii worm,' Alvinella pompejana, an annelid from a deep sea hot hydrothermal vent environment. Mar Biol Lett 5:191-201

Editorial responsibility: Hans Heinrich Janssen, Oldendorf/Luhe, Germany
Toulmond A, El Idrissi Slitine F, De Frescheville J, Jouin C (1990) Extracellular hemoglobins of hydrothermal vent annelids: structural and functional characteristics in three alvinellid species. Biol Bull 179:366-373

Tunnicliffe V (1988) Biogeography and evolution of hydrothermal-vent fauna in the eastern Pacific Ocean. Proc $\mathrm{R}$ Soc Lond B Biol Sci 223:347-366

Tunnicliffe V (1991) The biology of hydrothermal vents: ecology and evolution. Oceanogr Mar Biol Annu Rev 29: 319-407

> Tunnicliffe V, Desbruyères D, Jollivet D, Laubier L (1993) Systematic and ecological characteristics of Paralvinella sulfincola Desbruyères and Laubier, a new polychaete (family Alvinellidae) from northeast Pacific hydrothermal vents. Can J Zool 71:286-297

Von Brandt TF (1927) Stoffbestand und Ernährung einiger Polychäten und anderer mariner Würmer. J Comp Physiol A 5:643-698

Yancey PH (2001) Water stress, osmolytes and proteins. Am Zool 41:699-709

Yancey PH (2005) Organic osmolytes as compatible, metabolic and counteracting cytoprotectants in high osmolarity and other stresses. J Exp Biol 208:2819-2830

Yancey PH, Blake WR, Conley J (2002) Unusual organic osmolytes in deep-sea animals: adaptations to hydrostatic pressure and other perturbants. Comp Biochem Physiol A Mol Integr Physiol 133:667-676

Submitted: September 30, 2008; Accepted: January 19, 2009 Proofs received from author(s): April 7, 2009 